\title{
SIFAT ORGANOLEPTIK ES KRIM DENGAN PENAMBAHAN UBI JALAR UNGU (Ipomea batatas L)
}

\author{
Aprilawati Daeng Lanusu, S. E. Surtijono, L. Ch. M. Karisoh, E.H.B. Sondakh
}

Fakultas Peternakan Universitas Sam Ratulangi Manado 95115

\begin{abstract}
ABSTRAK
Tujuan penelitian ini untuk mengetahui pengaruh penambahan ubi jalar ungu terhadap sifat organoleptik es krim. Bahan yang digunakan adalah susu segar ubi jalar ungu dan bahan pembentuk es krim lainnya. 4 perlakuan yang diuji dalam penelitian ini terdiri dari P0 (1000 $\mathrm{ml}$ susu tanpa ubi jalar ungu), P1 (1000 ml susu ditambah ubi jalar ungu $150 \mathrm{~g}), \mathrm{P} 2$ (1000 $\mathrm{ml}$ susu ditambah ubi jalar ungu $300 \mathrm{~g}$ ), P3 (1000 ml susu ditambah ubi jalar ungu 450 g). Percobaan ini menggunakan rancangan acak lengkap dan dinilai oleh 35 Orang panelis untuk menentukan sifat organoleptik dari produk es krim ubi jalar ungu. Pengukuran data organoleptik menggunakan skala hedonik yang terdiri dari variabel warna, aroma, tekstur, citarasa. Untuk menentukan perbedaan perlakuan dilakukan dengan uji DMRT. Hasil penelitian ini menunjukan bahwa perlakuan memberikan pengaruh sangat nyata $(\mathrm{P}<0,01)$ terhadap warna, aroma, tekstur, citarasa es krim. Kesimpulannya adalah berdasarkan sifat organoleptik, penggunaan 450 gram ubi jalar ungu sebagai bahan tambahan pada $1000 \mathrm{ml}$ susu dapat digunakan dalam pembuatan es krim.
\end{abstract}

Kata kunci : Es krim, Ubi Jalar Ungu, Sifat Organoleptik

*Korespondensi (corresponding author) Email: edmund1403@gmail.com

ABSTRACT

\section{ORGANOLEPTIC} CHARACTERISTICS OF ICE CREAM ADDING BY PURPLE SWEET POTATOES (Ipomea batatas L). This study was conducted to know about the use of purple sweet potatoes as an extender to ice cream on the organoleptic characteristics. The material used in this study were fresh milk, purple sweet potatoes and the ingredients for ice cream making. Four treatments tested in this study consisted of P0 (1000 ml of milk without purple sweet potatoes), P1 (1000 ml of milk plus purple sweet potatoes $150 \mathrm{~g}), \mathrm{P} 2$ (1000 $\mathrm{ml}$ of milk plus purple sweet potatoes 300 g), P3 (1000 ml of milk plus purple sweet potatoes $450 \mathrm{~g}$ ). This research used a complete randomized design and was tested by 35 of panelist to determine the organoleptic properties data of a purple sweet potato ice cream product. The data measured of in this research used hedonic scale. The variables measured consisted of color, flavor, texture, taste of ice cream. Determination of difference of average was done by DMRT test. The results of this study showed that the treatment was significant effect on color, flavor, texture and taste $(\mathrm{P}<0.01)$. The conclusion of this study based on organoleptic characteristics, the use of $450 \mathrm{~g}$ of purple sweet potatoes as an additive in $1000 \mathrm{ml}$ of milk can be used on making of ice cream.

Keywords: Ice cream, Purple Sweet Potato, Organoleptic Properties 


\section{PENDAHULUAN}

Susu merupakan cairan yang berwarna putih yang disekresi oleh kelenjar mamae hewan mamalia betina sebagai bahan makanan yang mempunyai nilai gizi tinggi dengan kandungan nutrisi yang lengkap dan cukup untuk memenuhi kebutuhan bagi yang mengkonsumsinya. Susu sangat mudah rusak dan tidak tahan lama di simpan kecuali telah mengalami pengolahan. Baik susu segar mentah maupun susu pasteurisasi jika disimpan pada suhu yang dingin, susu tersebut mempunyai masa simpan yang terbatas, oleh karena itu perlu penanganan dan pengolahan yang tepat guna mempertahankan nilai gizinya. Agar mempunyai daya simpan yang lama dibuatlah salah satu produk olahan dari susu yaitu es krim.

Es krim merupakan produk susu beku yang dibuat dengan membekukan adonan. Es krim tersusun dari campuran bahan pangan seperti produk susu, bahan pemanis, stabilizer, bahan penambah citarasa dan telur. Es krim mempunyai rasa yang lezat, aromanya harum, warnanya menarik, dan teksturnya yang lembut. Komposisi es krim sangat bervariasi tergantung dari jenisnya. Komposisi ratarata es krim yang baik adalah Lemak 12\%, padatan susu bukan lemak (MSNF, singkatan dari "milk solid non fat") 11\%, gula $15 \%$, stabilizer dan emulsifier $0,3 \%$ dan padatan total 38,3\% (Arbuckle, 1986).

Dipasaran dikenal berbagai macam jenis es krim dengan aneka warna dan rasa yang lezat tetapi tidak menjamin segi keamanan pangan bagi kesehatan kosumen. Berbagai produk es krim komersial sering menggunakan pewarna sintetik yang dapat memberikan efek karsinogenik bagi kesehatan konsumen. Penggunaan pewarna sintetik pada makanan cukup kontroversial dan sangat dihindari oleh konsumen, karena dihubungkan dengan dampaknya pada kesehatan. Hal ini menjadi alasan untuk mencari jenis pewarna alami sebagai campuran dalam produk olahan es krim. Pewarna alami yang baik dan menguntungkan bagi kesehatan tubuh adalah ubi jalar ungu.

Ubi jalar ungu dapat tumbuh baik di dataran rendah maupun di pegunungan. Sejak tahun 1960, ubi jalar ungu sudah tersebar ke beberapa daerah di Indonesia seperti Jawa barat, Jawa tengah, Jawa timur, Papua dan Sumatra. (Santoso dan Estiasih, 2014). Potensi dari ubi jalar ungu adalah adanya pigmen antosianin pewarna alami yang menghasilkan penampilan menarik pada produk olahan juga berperan dalam mencegah terjadinya penuaan, kemerosotan daya ingat dan kepikunan serta penyakit jantung koroner dan penyakit kanker. Selain itu antosianin juga memiliki kemampuan sebagai antimutagenik dan 
antikarsinogenik terhadap mutagen dan karsinogen, mencegah gangguan pada fungsi hati, antihipertensi dan menurunkan kadar gula darah.

Serat alami oligosakarida yang tersimpan dalam ubi jalar ungu merupakan komoditas yang bernilai dalam penganekaragaman produk pangan olahan (Santoso dan Estiasih, 2014). Ubi jalar ungu mengandung antosianin berkisar kirakira $519 \mathrm{mg} / 100$ gr berat basah ( Steed and Truong, 2008). Ubi jalar ungu bisa menjadi anti kanker karena didalamnya ada zat aktif yang dinamakan selenium dan iodin yang aktivitasnya dua puluh kali lebih tinggi dari jenis ubi lainnya (Husna et. al., 2013).

Penilaian organoleptik dapat digunakan untuk menentukan kualitas dan membuat keputusan dalam mengkonsumsi es krim. Berdasarkan permasalahan diatas maka telah dilakukan penelitian tentang sifat organoleptik es krim dengan penambahan ubi jalar ungu (ipomoea batatas L).

\section{MATERI DAN METODE PENELITIAN}

\section{Waktu dan Tempat Penelitian}

Penelitian ini telah dilaksanakan pada tanggal 14 November - 14 Desember 2016 di Laboratorium Teknologi Hasil
Ternak, Fakultas Peternakan Universitas Sam Ratulangi, Kota Manado.

\section{Materi Penelitian}

\section{Bahan}

Bahan dasar dalam penelitian ini adalah : Susu segar $4000 \mathrm{ml}$, susu skim milk 800 gram, whippy cream 800 gram, agar-agar bubuk 28 gram, gula pasir 800 gram dan kuning telur 16 butir, ubi jalar ungu 900 gram.

\begin{abstract}
Alat
Peralatan yang digunakan dalam penelitian antara lain : kompor gas, panci, sendok kayu, mangkuk tempat bahan, spatula, pisau, gunting, gelas plastik, sendok es krim, gelas ukur, mixer, blender, timbangan, freezer, dan alat uji organoleptik yaitu tissue, aqua dan ketimun, kertas kuisioner dan alat tulis.
\end{abstract}

\section{Metode Penelitian}

Penelitian ini dirancang dengan menggunakan Rancangan Acak Lengkap (RAL) (Steel and Torrie, 1995). Data yang diperoleh dianalisis dengan Anova yang terdiri dari 4 perlakuan dan 35 orang panelis tidak terlatih sebagai ulangan. Penelitian ini menggunakan uji mutu hedonik. Apabila terdapat perbedaan antar perlakuan dilakukan uji DMRT. 
Tabel 1. Formulasi Es Krim Dengan Penambahan Ubi Jalar Ungu

\begin{tabular}{lllll}
\hline \multirow{2}{*}{ Bahan } & \multicolumn{4}{c}{ Perlakuan } \\
\cline { 2 - 5 } & P0* & P1 & P2 & P3 \\
Susu UHT & $1000 \mathrm{ml}$ & $1000 \mathrm{ml}$ & $1000 \mathrm{ml}$ & $1000 \mathrm{ml}$ \\
Susu skim milk & $200 \mathrm{~g}$ & $200 \mathrm{~g}$ & $200 \mathrm{~g}$ & $200 \mathrm{~g}$ \\
Whippy cream & $200 \mathrm{~g}$ & $200 \mathrm{~g}$ & $200 \mathrm{~g}$ & $200 \mathrm{~g}$ \\
Agar - agar & $7 \mathrm{~g}$ & $7 \mathrm{~g}$ & $7 \mathrm{~g}$ & $7 \mathrm{~g}$ \\
Telur & $4 \mathrm{butir}$ & $4 \mathrm{butir}$ & $4 \mathrm{butir}$ & $4 \mathrm{butir}$ \\
Gula pasir & $200 \mathrm{~g}$ & $200 \mathrm{~g}$ & $200 \mathrm{~g}$ & $200 \mathrm{~g}$ \\
Ubi jalar ungu & $0 \mathrm{~g}$ & $150 \mathrm{~g}$ & $300 \mathrm{~g}$ & $450 \mathrm{~g}$ \\
\hline
\end{tabular}

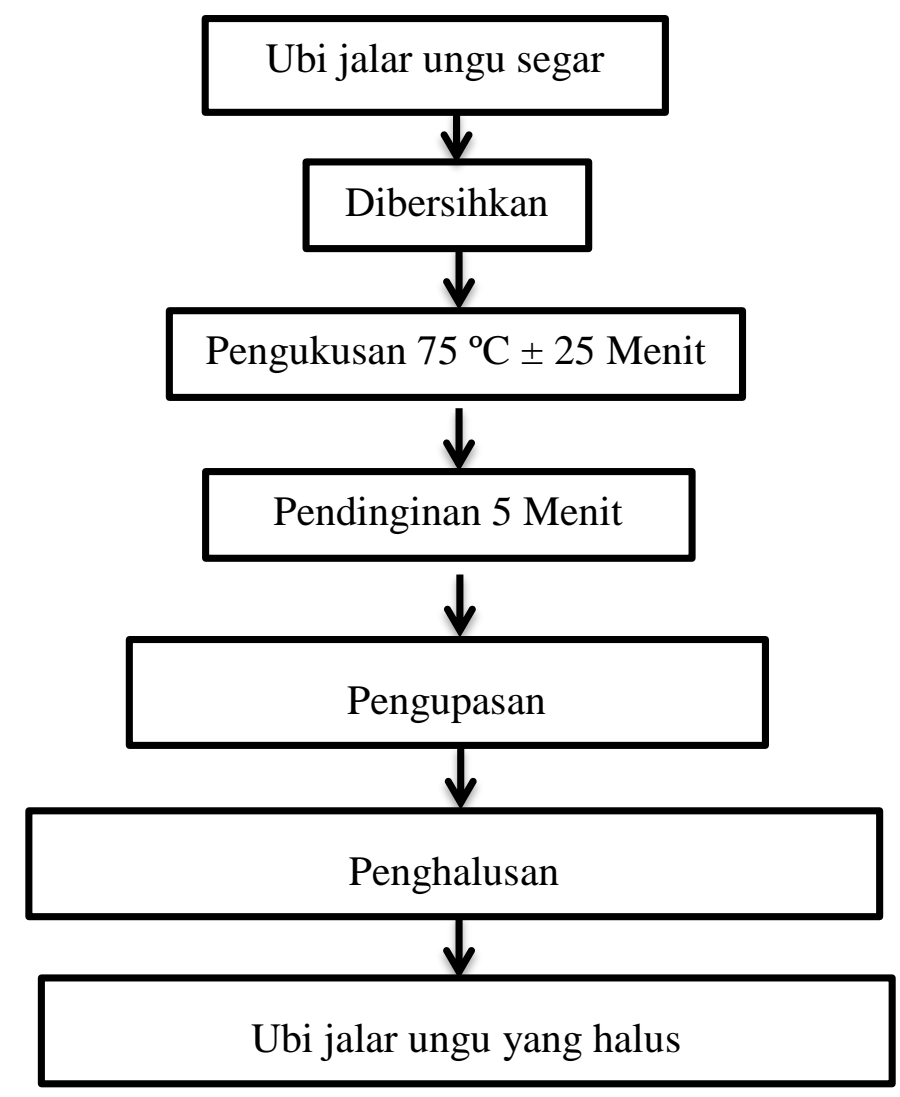

Gambar 1 : Diagram alir proses persiapan dan penghalusan ubi jalar ungu 


Gula pasir + kuning
telur dimixer sampai
mengental \&
berwarna agak putih
selama 30 Menit

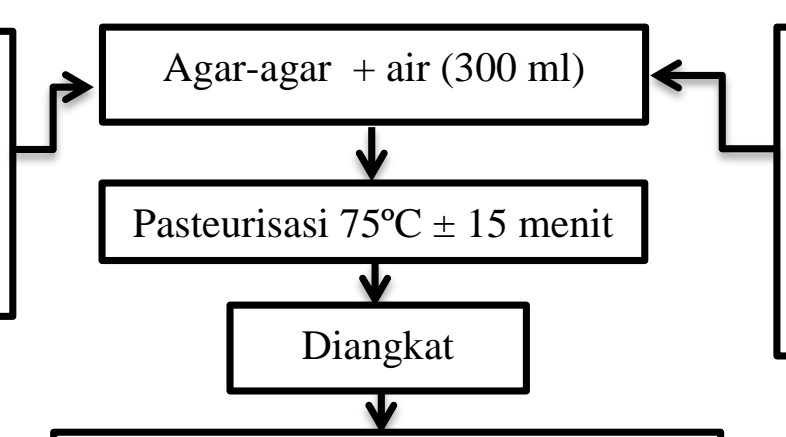

Dimasukkan dalam wadah bersih dan diamkan hingga dingin

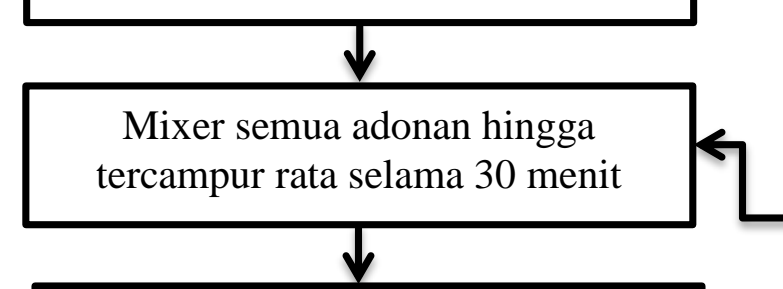

$$
\begin{gathered}
\text { Penyimpanan freezer selama } \\
\text { minimum } 4 \text { jam }-18^{\circ} \mathrm{C}
\end{gathered}
$$

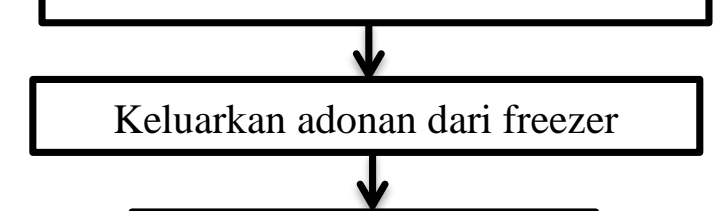

Mixer selama 30 menit

Penyimpanan freezer sampai setengah beku selama $2,5 \mathrm{jam}-30^{\circ} \mathrm{C} \mathrm{s} / \mathrm{d} 40^{\circ} \mathrm{C}$

Keluarkan adonan dan Mixer selama 30 menit
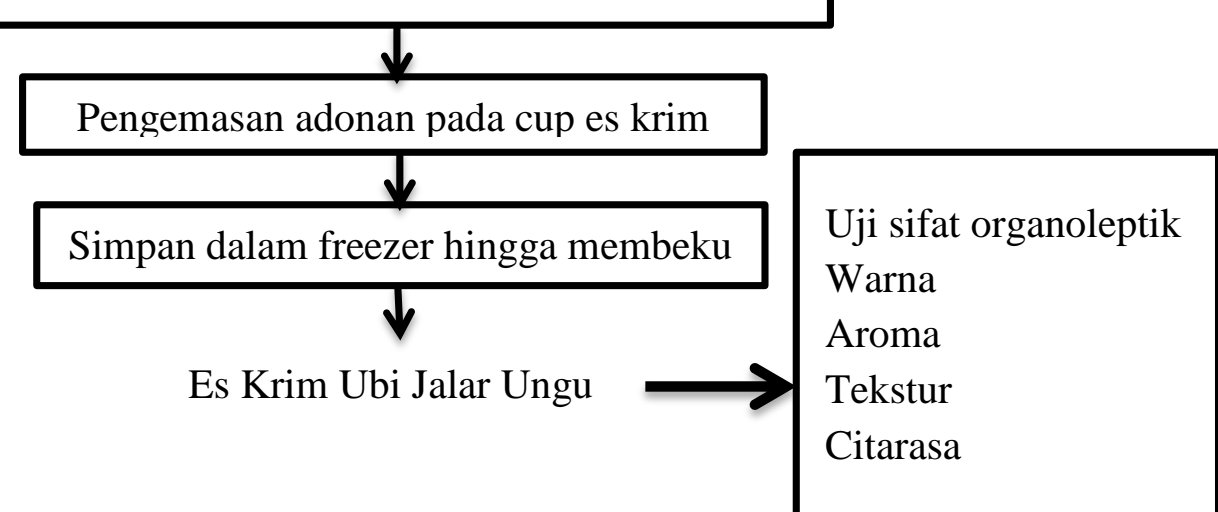

Gambar 2 : Diagram alir proses pembuatan es krim ubi jalar ungu 


\section{Variabel Penelitian}

Variabel yang diamati adalah sifat organoleptik daging yaitu warna, aroma, tekstur dan citarasa yang disajikan menggunakan format uji. Penelitian ini menggunakan uji organoleptik dengan skala hedonik 1 sampai 7 , panelis yang digunakan adalah panelis tidak terlatih yaitu 35 orang (Rahayu, 2001).

\section{HASIL DAN PEMBAHASAN}

Hasil pengamatan sifat organoleptik es krim dengan penambahan ubi jalar ungu disajikan dalam Tabel 2.

\section{Warna Es Krim Ubi Jalar Ungu}

Warna merupakan kesan pertama dari suatu produk yang menentukan penerimaan atau penolakan panelis terhadap produk tersebut.

Data hasil pengamatan untuk sifat organoleptik es krim dengan penambahan ubi jalar ungu terhadap warna es krim, dapat dilihat pada Tabel 2. Data menunjukkan bahwa tingkat kesukaan panelis terhadap warna es krim dengan penambahan ubi jalar ungu pada konsentrasi yang berbeda memberikan kisaran rataan 4.94 (Agak menarik) sampai 6.54 (Menarik).

Hasil analisis sidik ragam menunjukkan bahwa perlakuan penambahan ubi jalar ungu dengan konsentrasi yang berbeda berpengaruh sangat nyata terhadap warna es krim dibandingkan dengan tanpa penambahan ubi jalar ungu.

Berdasarkan hasil uji lanjut menggunakan uji DMRT menunjukkan bahwa perlakuan P0 berbeda sangat nyata $(\mathrm{P}<0.01)$ terhadap $\mathrm{P} 1, \mathrm{P} 2$ dan $\mathrm{P} 3$, dan perlakuan P1 tidak berbeda nyata terhadap $\mathrm{P} 2$ tetapi berbeda sangat nyata $(\mathrm{P}<0.01)$ terhadap P3.

Data hasil uji organoleptik warna es krim menunjukkan bahwa penambahan ubi jalar ungu $45 \%$ lebih disukai panelis dibandingkan es krim yang tidak ditambahkan ubi jalar ungu. Tingkat kesukaan terhadap warna es krim yang diberikan panelis diduga karena ubi jalar mengandung pigmen antosianin yang memberikan warna ungu yang menarik pada es krim. Warna ungu pada es krim lebih menarik dibandingkan warna es krim tanpa ubi jalar ungu. Demiikian juga di amati pada data $\mathrm{P} 1, \mathrm{P} 2$, dan P3. Panelis memberikan penilaian tingkat kesukaan warna lebih tinggi pada perlakuan P3 dibandingkan dengan P1. Daya tarik warna ungu yang ditampilkan pada P3 memberikan kesan lebih menarik dibandingkan dengan warna ungu pada perlakuan P1. Menurut Winarti et al. (2008), antosianin merupakan pigmen 
Tabel 2. Rataan Sifat Organoleptik Es Krim dengan Penambahan Ubi Jalar Ungu

\begin{tabular}{lllll}
\hline \multirow{2}{*}{ Variabel } & \multicolumn{4}{c}{ Perlakuan penambahan ubi jalar ungu (\% dari $1000 \mathrm{ml})$} \\
\cline { 2 - 5 } & $\mathrm{P} 0(0 \%)$ & $\mathrm{P} 1(15 \%)$ & $\mathrm{P} 2(30 \%)$ & $\mathrm{P} 3(45 \%)$ \\
\hline Warna & $4,94^{\mathrm{a}}$ & $5,46^{\mathrm{b}}$ & $5,60^{\mathrm{b}}$ & $6,54^{\mathrm{c}}$ \\
Aroma & $5,26^{\mathrm{a}}$ & $5,31^{\mathrm{a}}$ & $5,43^{\mathrm{a}}$ & $5,89^{\mathrm{b}}$ \\
Tekstur & $4,94^{\mathrm{a}}$ & $5,40^{\mathrm{ab}}$ & $5,48^{\mathrm{b}}$ & $6,34^{\mathrm{c}}$ \\
Cita Rasa & $4,63^{\mathrm{a}}$ & $5,17^{\mathrm{b}}$ & $5,88^{\mathrm{c}}$ & $6.57^{\mathrm{d}}$ \\
\hline
\end{tabular}

Keterangan: Superskrip berbeda pada baris yang sama artinya berbeda sangat nyata $(\mathrm{P}<0,01)$

alami yang berpotensi memberikan warna alami sehingga menghasilkan penampilan yang menarik pada produk olahan. Warna alami dari ubi jalar ungu memberikan intensitas warna ungu yang stabil.

\section{Aroma Es Krim Ubi Jalar Ungu}

Aroma merupakan salah satu komponen yang penting dalam penilaian konsumen terhadap suatu produk.

Data hasil pengamatan untuk sifat organoleptik es krim dengan penambahan ubi jalar ungu terhadap aroma es krim, dapat dilihat pada Tabel 2. Rataan tingkat kesukaan panelis terhadap aroma es krim berkisar antara 5,26 (Agak suka) sampai 5,89 (Suka).

Berdasarkan hasil analisis sidik ragam menunjukkan bahwa perlakuan penambahan ubi jalar ungu dengan konsentrasi 15-45\% memberikan pengaruh sangat berbeda nyata $(\mathrm{P}<0.01)$ terhadap tingkat kesukaan aroma es krim dibandingkan dengan tidak ditambahkan ubi jalar ungu.

Hasil uji lanjut menggunakan uji DMRT menunjukkan bahwa perlakuan P0 tidak berbeda nyata terhadap P1 dan P2 tetapi $\mathrm{P} 1$ berbeda sangat nyata $(\mathrm{P}<0.01)$ terhadap P3. Dan perlakuan P1 berbeda sangat nyata $(\mathrm{P}<0.01)$ terhadap $\mathrm{P}$ 3. Perlakuan P2 berbeda sangat nyata $(\mathrm{P}<0.01)$ terhadap P3. Penambahan ubi jalar ungu $0 \%$ sampai $35 \%$ belum memberikan perbedaan terhadap tingkat aroma. Perbedaan tingkat aroma muncul ketika ubi jalar ungu ditambahkan pada es krim sebanyak 45\%. Hal ini karena panelis lebih menyukai aroma ubi jalar ungu. Sejalan dengan pendapat Filiyanti et al. (2013) proporsi penambahan ubi jalar ungu mempengaruhi aroma dari es krim. Semakin banyak proporsi penambahan ubi ungu maka aroma yang dihasilkan juga semakin kuat. 


\section{Tekstur Es Krim Ubi Jalar Ungu}

Data hasil pengamatan untuk sifat organoleptik es krim dengan penambahan ubi jalar ungu terhadap tekstur es krim, dapat dilihat pada Tabel 2. Data menunjukan bahwa tingkat kesukaan panelis terhadap tekstur es krim dengan penambahan ubi jalar ungu yang berbeda, terdapat pada kisaran rataan 4,94 (Agak halus) sampai 6,34 (Halus).

Hasil analisis sidik ragam menunjukkan bahwa perlakuan penambahan ubi jalar ungu dengan konsentrasi yang berbeda berpengaruh sangat nyata terhadap tekstur es krim yang dihasilkan.

Berdasarkan hasil uji lanjut menggunakan uji DMRT menunjukkan bahwa perlakuan P0 tidak berbeda nyata terhadap P1 tetapi P0 berbeda sangat nyata $(\mathrm{P}<0.01)$ terhadap $\mathrm{P} 2$ dan $\mathrm{P}$. Dan perlakuan P1 tidak berbeda nyata terhadap P2 tetapi berbeda sangat nyata $(\mathrm{P}<0.01)$ terhadap P3. Perlakuan P2 berbeda sangat nyata $(\mathrm{P}<0.01)$ terhadap $\mathrm{P} 3$. Penambahan $30 \%-45 \%$ ubi jalar ungu memberikan tekstur es krim lebih halus dibandingkan es krim yang tidak ditambahkan ubi jalar ungu. Es krim yang mengandung 45\% ubi jalar ungu mengandung tekstur yang halus dan paling disukai oleh panelis. Menurut Filiyanti et al. (2013) bahwa unsur karbohidrat pada ubi jalar ungu pada proses pembuatan es krim berfungsi meningkatkan tekstur dan menstabilkan daya ikat air yang berpengaruh pada kekentalan dan tekstur es krim yang lembut. Hal ini sejalan dengan pendapat Arbuckle (1986) bahwa tekstur yang lembut pada es krim sangat dipengaruhi oleh komposisi campuran, pengolahan dan penyimpanan.

\section{Cita Rasa Es Krim Ubi Jalar Ungu}

Data hasil pengamatan untuk sifat organoleptik es krim dengan penambahan ubi jalar ungu terhadap cita rasa es krim, dapat dilihat pada Tabel 2. Data menunjukan bahwa tingkat kesukaan panelis terhadap cita rasa es krim dengan penambahan ubi jalar ungu yang berbeda, terdapat pada kisaran rataan 4,63 (Agak enak) sampai 6,57 (Enak). Nilai rataan skor tertinggi diperoleh pada perlakuan P3 yakni penambahan ubi jalar ungu $45 \%$ dan terendah pada perlakuan P0 tanpa ubi jalar ungu.

Hasil analisis sidik ragam menunjukkan bahwa perlakuan penambahan ubi jalar ungu dengan konsentrasi yang berbeda berpengaruh sangat nyata $(\mathrm{P}<0.01)$ terhadap citarasa es krim yang dihasilkan.

Berdasarkan hasil uji lanjut menggunakan uji DMRT menunjukkan bahwa perlakuan P0 berbeda sangat nyata (P>0.01) terhadap P1, P2 dan P3. Dan perlakuan P1 berbeda sangat nyata 
(P>0.01) terhadap P2, dan P3. Perlakuan P2 berbeda sangat nyata $(\mathrm{P}>0.01)$ terhadap $\mathrm{P} 3$. Terdapat perbedaan P0, P1, P2, P3 terhadap citarasa seiring dengan semakin banyak penambahan ubi jalar ungu pada es krim. Penambahan ubi jalar ungu $45 \%$ pada es krim memberikan daya tarik tersendiri terhadap citarasa dan panelis merekomendasikan bahwa penambahan 45\% ubi jalar ungu adalah citarasa yang enak dan paling disukai panelis. Ubi jalar ungu merupakan salah satu komponen bahan pangan yang disukai dalam menentukan citarasa. Susilawati et al. (2014) menyatakan bahwa pada ubi jalar ungu mengandung senyawa sukrosa yang memberikan efek manis sehingga es krim menjadi lebih enak.

\section{KESIMPULAN}

Berdasarkan hasil dan pembahasan bahwa penambahan ubi jalar ungu $45 \%$ (450 g) dalam es krim memberikan sifat organoleptik yang baik.

\section{DAFTAR PUSTAKA}

Arbuckle, W.S. 1986. Ice Cream. Avi Publishing Company. Inc. London

Filiyanti, I., D. R. Affandi, dan B. S. Amanto. 2013. Kajian penggunaan susu tempe dan ubi jalar ungu sebagai pengganti susu skim pada pembuatan es krim nabati berbahan dasar santan kelapa. Jurnal Tekno sains Pangan Vol 2 (2):2302-0733.

Husna, el Nida, Melly Novita dan Syarifah Royana. 2013. Kandungan antosianin dan aktivitas antioksidan ubi jalar ungu segar dan produk olahannya. Jurnal Teknologi Pangan 33 (3): 2680-5194.

Rahayu, W.P. 2001. Penuntun Praktikum Penilaian Organoleptik. Jurusan Teknologi Pangan dan Gizi. Fakultas Teknologi Pertanian. IPB. Bogor.

Santoso. W. E. A dan T. Estiasih. 2014. Kopigmentasi Ubi Jalar Ungu. Jurnal Pangan dan Agroindustri Vol.2(4): 121-127.

Steed, L. E dan V. D. Truong. 2008. Anthocyanin Content, Antioxidany Activity, And Selected Physical Properties of Flowable Purple Fleshed Sweet Potato Purees. Journal of Food Science. 73:215225

Steel. R.G.D. and J.H. Torrie. 1994. Prinsip dan Prosedur Statistika. Gramedia Pustka Utama, Jakarta.

Susilawati, F. Nurainy, A. W. Nugraha. 2014. Pengaruh penambahan ubi jalar ungu terhadap sifat organoleptik es krim susu kambing peranakan etawa, Jurnal Teknologi dan Industri Hasil Pertanian Volume 19(3):243-256

Winarti, S., U. Syarofa dan D. Anggrahini. 2008. Ekstraksi dan stabilisitas warna ubi jalar ungu (Ipomoea batatas L.) sebagai pewarna alami. Jurnal Teknik Kimia, Volume 3 (1): 207-214 